\title{
How low can we go? The limits of monetary policy
}

\author{
Steven Pressman* \\ Department of Economics, Colorado State University, Fort Collins, CO, USA
}

Central banks have recently pushed interest rates below zero. This was done after some considerable time with interest rates being near zero and unemployment remaining very high in many countries. The hope was that negative rates would reinvigorate monetary policy and rescue countries suffering from high unemployment and slow growth. This paper argues that negative rates are not an effective solution to the problems of high unemployment and economic stagnation, and that this policy proposal fails to understand both the nature of negative interest rates and how far interest rates might be pushed below zero percent. Rates a little bit below zero are possible because of insurance and carrying costs. Anything substantially below this would result in considerable economic harm that would exceed any economic benefits from the lower rates. This being the case, fiscal policy must be the policy of choice in difficult economic times.

Keywords: NIRP, monetary transmission, monetary policy, negative interest rates

JEL codes: $E 4, E 5, E 6, G 2$

\section{INTRODUCTION}

Macroeconomics today is quite unlike macroeconomics in the past, particularly regarding interest rates. Homer and Sylla (2005) proffer no instances, throughout 5000 years of human history, of nominal interest rates going negative, although the Swiss National Bank did push rates on foreign deposits below zero in the 1970s to prevent capital inflows and currency appreciation. Yet shortly after the last edition of their classic work was published this was no longer true. During the Great Recession, central banks lowered interest rates below zero on bank reserves as a way around the zero lower bound (ZLB). Furthermore, \$11.7 trillion of negative-yield sovereign debt has circulated, including $\$ 7.9$ trillion of Japanese securities and more than $\$ 1$ trillion of French and German securities (Durden 2016).

This paper examines whether negative interest rates can help developed nations solve their current macroeconomic problems. It answers 'no' because there are limits to how far rates can be pushed below zero, and because, at some point, negative interest rates do more harm than good. We proceed as follows. Section 2 provides a brief history of negative interest rates. Section 3 explains why rates cannot be pushed very far below zero. Sections 4 and 5 explain why interest rates a bit below zero cannot solve serious macroeconomic problems. Section 6 concludes by arguing for a revitalized fiscal policy.

* Email: pressman@monmouth.edu. 


\section{A HISTORY OF NEGATIVE INTEREST RATES}

The ZLB problem is implicit in Keynes's (1936) discussion of how liquidity demand could prevent interest rates from falling and, even earlier, in Silvio Gesell's (1916 [1958]) proposal that currency should pay negative interest rates. More recently, Don Patinkin (1948), William Vickrey (1954), Edmund Phelps (1972), and Arthur Okun (1981) mentioned the possibility of a negative interest rate equilibrium.

One way to think about this problem is via the standard IS-LM model, in which the goods market and money market simultaneously clear to deliver an equilibrium level of income and an equilibrium interest rate. ${ }^{1}$ Analytically, a problem arises if full employment requires a negative interest rate.

The possibility that real economies might require interest rates below zero is not just a modeling artefact. It has arisen in Japan where the economy has remained mired in stagnation despite interest rates being reduced to near zero (Krugman 1998). It surfaced again at the March 2009 open-market committee meeting when Janet Yellen (then President of the San Francisco Federal Reserve) stated that the federal funds rate would have to fall to -6 percent in order to reach full employment using monetary policy (Ball et al. 2016, p. 7).

Initially, central banks did not think they could push interest rates below zero. Traditionally, economists have viewed interest as a way to encourage savings and as a reward for delaying consumption. It was assumed that people prefer goods now rather than in the future and must be paid not to consume. Moreover, savers were seen as risk-averse, unwilling to give financial institutions their money unless paid to do so. That requires positive rates of interest at all times. In addition, most economists and central bankers thought that if banks were charged interest by central banks, and banks passed their costs on to customers, those customers would withdraw money from the banking system to avoid losing money. Financial disintermediation, it was feared, would reduce investment and lead to another Great Depression. So, for all the above reasons, it was believed that developed economies could not function with negative interest rates.

Technically, negative rates are possible. Central banks require banks to hold reserves against their deposit liabilities and can pay or charge interest to banks for required reserves or excess reserves held at the central bank. Also, central banks can indirectly affect other interest rates by using their standard policy levers. They can push interbank lending rates (for example, the federal funds rate) below zero by purchasing government securities and flooding banks with reserves. When the interest rate paid by the central bank on excess reserves is negative, banks will seek to get rid of excess reserves to avoid charges for carrying them, including lending them overnight to other financial institutions. Banks may even be willing to pay those institutions for the privilege of doing so (that is, accept negative interest rates), as long as the negative interest-rate penalty is less than the cost of holding excess reserves.

Central banks can also target interest rates on government or sovereign debt. If central banks bid-up bond prices above their face value, the bond pays a negative nominal interest rate. US government securities yielded negative nominal interest rates after the fall of Lehman Brothers in 2008, when investors sought safety and bid the price of US Treasuries above face value. Also, as noted earlier, there is currently nearly $\$ 12$ trillion

1. Post-Keynesians have criticized IS-LM, including Chick (1983), Weintraub (1961), and Robinson (1962), who referred to it as 'bastard Keynesianism.' However, the purpose of this paper is to show that even within standard macroeconomics there are limits to what a negative interest-rate policy can do to improve economic outcomes. 
of sovereign debt with negative interest rates. So, in practice as well as in principle, central banks can push several key interest rates into negative territory.

In the early 2010s, central bankers faced a dilemma: they felt damned if they cut rates below zero and triggered renewed financial instability, and damned if they did not do this and economies were drawn into a debt-deflation spiral. However, the Great Recession was a desperate time calling for desperate measures, and central banks leapt into the unknown.

The Danmarks Nationalbank (DN) was first to lower rates below zero in July 2012, attempting to stop money from flowing into the country during the euro crisis. Their approach, which was followed by most central banks, was to charge 0.2 percent interest on bank deposits (above a certain threshold) at the central bank. After turning positive in April 2014, the DN lowered rates below zero again in 2014. In early 2015, they reduced rates to -0.75 percent; one year later, rates were increased slightly, to -0.65 percent. The Hungarian Central Bank pushed deposit rates into negative territory ( -0.05 percent) in March 2016. The European Central Bank (ECB) went negative in June 2014 when it cut the rate it paid on bank deposits to -0.1 percent in an attempt to avoid deflation; in December 2014 they cut the rate further, to -0.2 percent. In March 2017, it stood at -0.4 percent. The Swiss National Bank cut deposit interest rates to -0.25 percent in December 2014 (effective January 2015) in an attempt to halt the appreciation of its currency and the effects of this on Switzerland's economy. When this had little impact, they lowered rates further to -0.75 percent in January 2015. The Svereiges Riksbank of Sweden cut the reverse repo rate to -0.1 percent in February 2015, then they gradually further reduced it to -0.5 percent by February 2016. The Central Bank of Japan pushed interest rates on excess reserves below zero in 2016. Norges Bank, the central bank of Norway, cut interest rates on bank deposits at the central bank to -0.25 percent in September 2015 and has since lowered the rate to -0.5 percent. In most cases, commercial banks have not passed these negative rates on to their customers, except for a few cases where large corporations were charged negative rates by banks (Jobst and Lin 2016).

\section{WHAT ARE NEGATIVE INTEREST RATES?}

To understand why negative interest rates cannot solve macroeconomic problems first requires understanding why someone would keep money in a bank when charged to do so. There are two main reasons for this: opportunity cost and safety.

As Keynes (1936, pp. 225-229) noted, there are several costs associated with holding money. One cost is the lost interest from holding money rather than another asset. Of course, once interest rates on assets approach zero, this cost approaches zero. Next there are carrying costs, or the cost of holding and storing money. Keynes mainly focused on the decision to hold money rather than bonds; however, a similar analysis works for the decision to hold cash rather than bank balances. If we keep bank balances to a bare minimum, we will need to store cash and at times bring it to a bank so that it can be transferred to others. There is also a risk of losing cash or it being destroyed. We can even update Keynes by adding one more cost. Large cash withdrawals and deposits can spur monitoring by bank authorities, suspicious of money laundering or tax evasion.

People and firms should be willing to hold cash only if their other options are worse. Money can be held in a safe or safe deposit box. Of course, there are costs of purchasing or renting these items; and there are costs of going to the bank and transferring money 
into checking accounts when making payments. As cash balances increase, so too does the cost of money transfers. $\$ 1$ million in $\$ 100$ bills weighs 22 pounds; $\$ 10$ million weighs 220 pounds.

If banks charged interest on deposits, institutions would arise to minimize carrying costs. These institutions would not charge interest; rather, they would charge fees to store cash and keep it safe. Still, this is equivalent to paying a negative interest rate on bank deposits, thereby putting a floor on how low interest rates can go (Garbade and McAndrews 2012). With rates only a bit below zero, alternative firms will not be able to charge much. People will keep their money in the bank, paying for the privilege of storing and keeping it safe at a bank. As rates become more negative, it pays to start a money storage business and charge a small fee. When exactly this will happen is not clear. Part of the problem is uncertainty. If negative rates are expected to last for a short time, economic agents will not incur substantial fixed costs such as purchasing a safe place to store money or moving cash to an alternative facility. When rates again become positive, cash will have to be moved back to a bank. However, if negative rates are expected to continue for a long time, it becomes worthwhile to incur those costs rather than being charged negative interest rates on bank deposits.

As rates fall further below zero, and as central banks signal that low negative rates will continue for a long period of time, more and more cash will be taken out of banks. Withdrawals will also reduce bank profits and bank capital, since banks make money on the difference between their lending rate and the rate they pay depositors. That will curtail bank lending due to capital requirements on banks (Admati and Hellwig 2013).

In addition to carrying costs, negative interest rates are a sort of insurance premium. It is the cost of keeping one's money safe. Safety comes from owning government securities, having money in bank accounts insured by the government, or in a bank deemed 'too big to fail.'

Sovereign debt constitutes the safest possible asset. After Lehman Brothers fell in September 2008, investors no longer believed that large financial institutions were too big to fail any longer. They bought government bonds for security, and willingly paid more than the face value of these bonds - turning over $\$ 100100000$ for a one-year bond whose value in one year would be only $\$ 100$ million. The extra $\$ 100000$, a negative interest rate, was really an insurance premium. At the time, bank deposits were not insured beyond $\$ 100000$, and putting this amount into 1000 different banks was unwieldy, time-consuming, and difficult. The easiest way to insure the money was to buy government bonds, even if the price was greater than its face value.

Seeing negative interest rates as an insurance premium helps understand why rates can go negative, but only by a small amount. Zero is not the minimum because people will pay something to keep their assets safe. However, people will pay only so much for insurance. At some point they will opt to hold cash, pay the transactions or carrying costs, and self-insure or find a firm willing to provide such insurance. At this point the lower bound on interest rates reasserts itself. The lower bound, therefore, is not zero; rather, it is the carrying cost and insurance premium that people and firms will pay to keep their money in financial institutions.

What is the effective lower bound? The Fed has estimated the carrying costs of money at around 0.35 percent (Burke et al. 2010). Annual home insurance also runs around 0.35 percent of the value of an insured home. Adding these figures together gives us an effective lower bound on interest rates of something close to -0.7 percent. Coincidentally, this figure is around the lowest that interest rates have been pushed (Burke et al. 2010; Witmer and Yang 2015). It is a bit less than zero, but still a 
lower bound. It is unlikely that monetary policy can cut rates to -1 percent, much less well below -1 percent.

There is some empirical evidence supporting a lower bound of around -0.7 percent. The small negative interest rates recently instituted in Denmark, Sweden, Switzerland, or the eurozone seem to have had little or no impact on bank withdrawals (Bech and Malkhozov 2016). Also, bank lending does not seem to have fallen when interest rates became slightly negative. Molyneux et al. (2017) find that lending did decline a bit. On the other hand, Bräuning and $\mathrm{Wu}$ (2017) and Demiralp et al. (2017) find that negative interest rates tend to increase bank lending. More than likely, there are opposing forces at work here. On the one hand, negative interest rates provide an incentive for banks to lend rather than hold excess reserves. However, if banks don't lower rates (because their costs have not fallen), loan demand may not be there. We would therefore expect to see little change and find no clear results from empirical studies.

Likewise, as interest rates have gone slightly negative, it is not clear that bank profitability has been hurt (Bech and Malkhozov 2016). The European Central Bank (ECB 2016) finds some decline in bank profitability when rates were lowered to negative levels, but this can be due to the poor economic conditions that led to both negative rates and reduced bank profitability from more loan defaults. Scheiber et al. (2016, chart 12) find little effect of the current regime of negative rates on bank profitability, except for the case of Denmark, where interest rates have gone a bit more negative than -0.7 percent.

Certainly, these may be just short-term results. Negative effects may not appear in the data until they are in place for a longer period of time and people expect that this will continue or be the new norm. However, they provide some evidence that interest rates must go below -0.7 percent before they do economic harm.

\section{REAL-WORLD BEHAVIOR IN A NEGATIVE INTEREST-RATE WORLD}

Whether negative interest rates can lead to full employment depends on the money transmission mechanism. The standard view is that interest-rate cuts have many positive economic effects (Bernanke 2007). It has a spending effect, encouraging borrowing for consumption and investment. It has an exchange-rate effect, depreciating the national currency and increasing net exports. It has a wealth effect, where lower interest rates push up asset prices and household wealth, generating more spending. Because higher asset prices also increase the net worth of banks, lower interest rates can lead to more bank lending because capital requirements will be less constraining (Boivin et al. 2010). Finally, cuts in interest rates may generate higher inflation, which then mitigates debt-deflation problems.

However, as Keynes (1936, p. 173) famously noted, there can be many slips between the cup and the lip, or many ways that lower interest rates can fail to increase spending. That is true when rates are above zero. When rates become negative, those problems can worsen, making it even less likely that negative rates can mitigate our macroeconomic problems.

First, neither interest-rate cuts nor negative interest rates can spur growth via the exchange-rate effect. There is a sort of paradox of thrift (Keynes 1936, p. 373; Palley 2016, pp. 12-13) here; what one country can do by lowering the value of its currency, all countries cannot do since all countries cannot simultaneously lower the value of their currency and spur exports to all other countries. When one nation cuts rates to depreciate their currency, other nations are likely to follow. And within the eurozone, 
where there is only one currency, that is not even possible. Consequently, the exchange-rate mechanism is highly suspect - both when positive interest rates drop and when interest rates go negative.

Second, negative interest rates can have adverse distributional consequences. Those putting their savings into assets will benefit from higher asset prices when interest rates are cut. In contrast, those who save in bank accounts may suffer as rates go negative because they may be charged for the privilege of holding bank deposits. Pushing rates down increases the share of total income going to those at the top of the distribution and lowers the share of income received by those in the middle and the bottom. That will reduce aggregate consumption and slow economic growth. Going from positive to negative rates may have an even worse distributional impact than just cutting positive interest rates since, rather than charging a negative rate, fees will likely be imposed on bank accounts with small average balances, particularly hurting those at the bottom of the income distribution.

In addition, behavior may change when rates go negative, but not when they are positive and falling toward zero. Negative rates may be a sort of tipping point because people are known to suffer from loss aversion (Kahneman and Tversky 1984). As rates fall below zero, banks will become increasingly likely to pass their additional costs to account holders. At this point the distributional consequences of negative interest rates become more pronounced. Some will be able to avoid these costs more; others will not. People and firms with a good deal of money can avoid negative interest rates more easily. Checks received may not be deposited until the money must be spent, or these checks can be immediately converted into cash. Taxes can be paid to the government far exceeding what is owed; this would result in money earning 0 percent interest rather than losing money in the banking system. The simplest way for individuals to do this would be to increase withholding from their pay check. Likewise bills can be paid before they are due. For example, mortgage and rent payments can be made months in advance, while college tuition can be paid years in advance, thereby enabling households to lower their bank balances. Those unable to pay bills and taxes far in advance will have to absorb the costs associated with negative rates. In addition, wealthy individuals can shift to holding gold, foreign money, or some cryptocurrency as an alternative to holding bank deposits. Finally, as banks raise fees, low-income individuals will abandon banks in favor of alternative financial institutions such as check-cashing outlets and payday lenders. Those institutions already charge higher fees than traditional banks, and they may further raise their fees due to the rising demand and the higher fees charged by banks.

There is a third reason negative interest rates may not spur economic growth: negative rates are a cost to banks and this will change bank behavior. Cutting rates from some positive number to zero reduces bank costs to obtain money and then lend it. In contrast, negative rates increase the cost to banks of holding excess reserves and thus increase bank costs. There is nothing to pass on to consumers in terms of lower interest rates that may spur greater spending. Facing greater costs, banks will tend to raise lending rates, leading to less borrowing and spending. Moreover, charging customers higher fees for keeping money in the bank can lead to withdrawals from the banking system (Palley 2016, p. 10). This, in turn, will lead to a shortage of bank reserves to back up account liabilities of banks. Banks will be forced to sell assets, lowering their price and their capital. Reduced bank capital will also force banks to curtail lending, which will hurt future profits and the entire economy (Ball et al. 2016, p. 30; Heider et al. 2016).

Furthermore, negative rates may reduce bank profitability. That will also reduce bank capital, and can cause bank capital requirements to constrain bank lending. To escape 
that constraint, banks may make riskier loans, but that puts banks at greater risk of loan default and increases financial fragility.

This is another instance when going negative makes a difference. Lower positive rates will improve profitability if banks are slow to reduce their lending rates. Banks also benefit from lower rates because loans are typically long-term assets with relatively fixed rates. As interest rates fall through positive territory this reduces the cost of obtaining funds to back their loan portfolio, which increases bank profits and equity. They might even be able to lend more and make even greater profits due to their higher level of capital. However, if negative interest rates lead to bank withdrawals, this will have the reverse effect. Banks short of deposits may have to sell some of their loans. This can lead to debt-deflation problems and large losses from default. This will further reduce asset prices and banks' net worth, which will reduce bank lending as the bank capital requirement becomes the constraining force on lending.

Fearing large withdrawals, banks may not pass their higher costs on to depositors. In this case, negative interest rates will hurt bank profitability because banks are reluctant to charge customers interest on their deposits for fear of losing them or banks may be prohibited from charging negative rates by law on certain accounts. With positive rates, bank can lower the rates they pay depositors with little adverse impact. When rates become negative, that is no longer true. Banks can try to compensate by raising fees, but this too can lead to bank withdrawals. Also, as we saw above, there are limits to the extent fees and negative rates can be imposed on depositors before they search for alternatives. Whatever the response, negative interest rates will result in less lending and less spending, and this relationship changes when rates become negative (Hannoun 2015; IMF 2016, pp. 44-46). Negative rates become a tipping point.

Besides impacting banks, negative interest rates will adversely affect pension funds, insurance companies, and other non-bank financial institutions (see Antolin et al. 2011) that face limited options regarding the assets they can hold. Asset managers at these institutions must earn certain rates of return in order to pay future liabilities, such as the pensions that have been promised to retirees. Most of these managers cannot legally purchase assets with a negative or zero yield. Regulations require they hold cash or AAA-rated bonds. If bank deposits and bonds both pay negative rates, pension funds cannot fulfill their obligations when people retire and insurance companies will be unable to fulfill their obligations following the death of a policy-holder. Furthermore, as interest rates turn negative, financial innovation will likely develop new securities deemed to be investment-grade and eligible for purchase by pensionfund managers, generating a speculative asset bubble (Hannoun 2015). This is exactly what happened with mortgage-backed securities, a major cause of the Great Recession. It is likely to happen again as interest rates become negative, increasing systemic risk throughout the economy.

Fourth, there is the question of liquidity preference or expectations, something stressed by Keynes and Post-Keynesian economists (see Kelton 2012). If negative interest rates indicate that central banks are worried about the economy, and if even more negative rates indicate greater worry, pushing rates below zero might reduce investment demand and bank lending. The end result may be a vicious cycle, with negative rates increasing the demand for cash and lowering investment demand, thereby necessitating even lower rates to try to revive spending.

Finally, there is an important practical issue. Does lowering rates from 0 percent to -0.7 percent make much difference? It is clear that large changes in interest rates will impact spending. In the 1980s, Paul Volker raised the US federal funds rate from 11.2 percent (1979) to 20 percent (in June 1980). The result was a steep decline in 
the US economy, with the unemployment rate reaching 10.8 percent in December 1982. Following the fall of Lehman Brothers, the Federal Reserve lowered interest rates from 4.75 percent in December 2007 to under 0.25 percent in December 2008, helping prevent the US economy from plunging into another Great Depression. But cutting interest rates half a percentage point (or a bit more) will increase growth and employment only marginally. In times of economic crisis more than that is needed.

\section{ARE NEGATIVE RATES FOR REAL?}

Most economists regard people as rational and immune to money illusion, meaning that real interest rates will impact decision-making and the economy. But central banks do not control real rates; they have to get real rates down by lowering nominal rates.

For policy purposes, the real-nominal difference matters little when interest rates and inflation rates are positive. That is because there is ample room to adjust nominal rates downward to yield the desired real rate. If inflation is 2 percent, and the central bank desires a 0 percent real interest rate, it can lower nominal rates to 2 percent; if it desires a -1 percent real interest, it lowers nominal rates to 1 percent. In deflationary times, however, things are more difficult. With deflation, a 0 percent nominal interest rate paid by borrowers yields a positive real rate for borrowers that is equal to the rate of deflation. A nominal rate of -0.7 percent yields a positive real rate of interest if prices fall by more than 0.7 percent. And if -0.7 percent is the effective lower bound on nominal rates, then central banks lack the power to get real rates down to near zero when prices are falling.

Keynesians and Post-Keynesians contend that both nominal rates and real rates impact spending and growth. Certainly, Keynes thought that it was the nominal rate of interest that affected investment (see Wray 2007). A good case can be made that consumer borrowing and spending is affected by what payments they can afford to make on a regular basis. Consumers borrow mainly because of liquidity constraints (Wilcox 1990), and so they will be constrained in their borrowing by how much they must pay each month, which depends on the nominal rate on the loan rather than on the real interest rate. In addition, firms and consumers only see the current nominal rate and the current inflation rate when making borrowing decisions. Money is borrowed for a long time period and real interest rates are not known. This point is clear in more recent macroeconomic models where central banks operate by controlling interest rates rather than the money supply. Here it is the nominal rate that gets changed in order to boost investment spending, consumption, and economic growth. Given that nominal rates control spending and given the limits to how low nominal rates can go, there are limits to the use of monetary policy. These limits are even greater than many Post-Keynesians have recognized.

Post-Keynesians ${ }^{2}$ have set forth two main approaches to monetary policy that depend on setting rules for the central bank to follow when setting interest rates. The Kansas City rule, or Wray (2007, p. 138) approach, says that central banks should set nominal interest rates 'at zero, and keep it there.' Wray contends this would lead to negative real rates, and is the most expansionary monetary policy rule. This is correct, but only during normal economic times. Ironically, Wray advanced his rule right

2. See Gnos and Rochon (2007) and Rochon and Setterfield (2008) on Post-Keynesian approaches to interest-rate policy. 
before the world encountered deflationary problems. During the Great Recession, central banks actually tried the Wray approach. Nominal rates were cut to near 0 percent, but real interest rates remained positive in a number of nations due to deflation. Central banks soon recognized that nominal interest rates had to be set below zero to counter deflation, to stimulate the economy, and to ensure full employment.

An alternative Post-Keynesian view, promulgated by John Smithin (2004, p. 65; 2007), holds that the real interest rate should be set at zero; that is, the nominal interest rate should be changed regularly and set equal to the actual rate of inflation. For Atesoglu and Smithin (2006), this would limit the ability of monetary policy to favor the wealthy or 'rentiers,' and would make monetary policy neutral as regards the distribution of income. High rates, they argue, benefit those at the top of the distribution who have accumulated more wealth and earn interest on it. At the same time, those at the bottom and middle of the income distribution, needing to borrow money, are forced to pay more when rates are high. Zero real interest rates would hurt 'rentiers' and help borrowers with low incomes and a higher marginal propensity to consume.

In a deflationary world, according to the arguments in this paper, the Smithin rule actually does worse than the Wray rule. If prices are falling, the Wray rule says to keep nominal rates at 0 percent. In contrast, the Smithin rule says that nominal interest rates should go negative. But, as argued earlier in this paper, once rates go below -0.7 percent, costs will rise for banks and these costs will be passed on to consumers seeking loans and wanting bank accounts. Less borrowing and spending will reduce growth and employment, making it more difficult for borrowers to repay loans. In addition, withdrawals from banks will force banks to sell assets, thereby lowering their prices. In addition, deflation of 1 percent requires -1 percent nominal rates. Even if possible, this would further slow the economy, putting additional downward pressure on prices. So, we may need -2 percent nominal rates to keep real rates at 0 percent. As this process continues, rates may need to be set at -5 percent or less to give us a real rate of 0 percent. Monetary policy that requires -6 percent nominal rates, when prices fall by 6 percent, would surely decimate the financial system. Firms and individuals will seek to hold cash rather than bank deposits if they were to lose substantial money on their deposits. They will find cheaper ways to store and insure money. Ultimately, the Smithin rule is just as impractical as mainstream models that require nominal interest rates to fall to -6 percent.

\section{CONCLUSION AND POLICY IMPLICATIONS}

Negative interest rates have done some good. Summarizing the literature on this topic, Siklos (2017, p. 195) contends that quantitative easing (QE) and near or below zero interest rates 'were successful at changing expectations regarding future short-term interest rates and thereby medium- and long-term rates.' Consequently, spending and economic growth were a bit greater than would have been the case had rates not gone negative (see also Jobst and Lin 2017). That is consistent with standard Keynesian macroeconomics. Moreover, as noted above, there is little evidence that negative rates hurt bank profitability. Again, that is not particularly surprising given that rates did not go very negative.

The important issue, though, is not the impact of small negative interest rates. It is whether central banks can lower rates substantially below zero. Monetary policy can help nations recover from economic crises only if that is possible. While there is no ZLB, this paper argues that there is an effective lower bound close to -0.7 percent. 
Depositors should be willing to pay a small premium to keep their money safe, and to minimize their transaction costs, but not a large one. Beyond this, negative rates will have negative economic consequences that positive or zero interest rates do not have.

If this analysis is correct, monetary policy cannot solve economic problems of the sort encountered by developed countries since 2008. If full employment requires interest rates of -6 percent, disintermediation will be large. Financial institutions will experience large withdrawals, bank profits and capital will fall, and developed nations will experience all the problems that economists feared would arise due to the ZLB. Effectively we have a lower bound on interest rates that is not zero, but some small negative number due to the carrying costs associated with holding cash and a desire to insure one's assets.

Economists and central bankers have viewed negative interest rates as a way around the ZLB. In some respects, this marks a return to mechanical or 'hydraulic' Keynesianism (Coddington 1976), where macroeconomic models crank out equilibrium solutions and necessary policy changes. But there is also a political economy side to pushing interest rates deep into negative territory. Believing interest rates can go substantially negative supports the belief that monetary policy can solve our economic problems and that fiscal policy is unnecessary. The rational expectations revolution and the rise of neoliberalism at the end of the twentieth century held that fiscal policy was destabilizing and ineffective (Lucas 1981). Macroeconomists came to see deficits as reducing confidence, and government spending as crowding-out other forms of spending. The infamous Reinhart and Rogoff (2010) paper $^{3}$ contended that once debt-to-GDP ratios reach 90 percent, fiscal stimulus actually lowers economic growth. This supported beliefs that reducing government budget deficits would raise confidence and increase spending. As a result, austerity was promulgated throughout the world. The practical result has been to rely only on monetary policy to improve economic performance. If we need to get interest rates to -5 percent or below, that's fine - as long we do not use a discredited fiscal policy.

However, if monetary policy is of limited effectiveness because it encounters a lower bound (slightly lower than zero) on interest rates, fiscal policy is required to deal with economic crises. During such periods, spending multipliers are likely to be even greater than during normal economic times. ${ }^{4}$ This means increasing government spending and/or cutting taxes in order to stimulate spending and economic growth. Even in a world where government deficits and debt have negative economic effects, there are fiscal policy options that will mitigate these effects.

One way to provide a fiscal stimulus relies on the balanced budget multiplier, an equal dollar increase in taxes and government spending (Samuelson 1948). Joseph Stiglitz (2010, p. 75) argued that this would allow governments to employ an expansionary fiscal policy without worrying about the impact of this on budget deficits or government debt. The state would tax income that otherwise would have been saved and then spend their additional tax receipts. Overall, there would be a small stimulus but no increase in government debt. In fact, tax collections would increase slightly as a result of the faster economic growth, so the budget deficit would actually fall. So too would the debt-toGDP ratio.

3. Herndon et al. (2014) identify some simple math errors in this paper that, when corrected, yield opposite results.

4. Charles et al. (2015) and Setterfield (2015) provide some explanations for why this might be so. 
Another possibility is for governments to borrow and spend for investment purposes - build schools, hospitals, and roads, as Keynes (1936) recommended (see Pressman 1994). If the focus is on what governments can do, and what business firms cannot or will not do, there should be little or no crowding-out. Government expenditures will also lead to improved economic efficiency and greater tax revenue in the future, enabling the state to repay its loans. To the list of items from Keynes we can add things such as child allowances and paid parental leave (Pressman 2014) as well as early childhood education (Bartik 2014; Heckman and Masterov 2007). These expenditures yield high rates of return due to the increased earnings when children become working adults. They also lower spending on crime prevention and for government programs that aid low-income individuals. Future gains, discounted for present values, would be sufficient to repay the debt incurred from present spending, with interest, and may even yield a small surplus.

A third option would focus on income distribution. As far back as The General Theory, Keynes (1936) noted that inequality was a problem because of its impact on effective demand and employment, and that fiscal policy would be more effective if it improved the distribution of income (see Pressman 1997). It is well known that inequality has risen in the US and most other developed countries over the past several decades (Galbraith 2016; Piketty 2015). One reason for this is that government tax policy has become markedly less progressive in its incidence. Corporate income taxes have fallen sharply as a percentage of government tax collections and individual income tax has become substantially less progressive in its incidence. In contrast, regressive sales and payroll taxes have risen sharply as a percentage of government revenues.

Although there is some dispute regarding the progressivity of corporate income tax, which concerns how much of the tax can be passed to consumers, most economists think that the tax is shared relatively equally between capital and labor (Felix and Hines 2009). The Brookings tax incidence model makes several different assumptions about tax shifting. Even under the conservative assumption that half the tax gets shifted to consumers, corporate income tax is more progressive than most other major tax revenue sources; the only exception here is individual income tax (Pechman 1985; Pechman and Okner 1974). Moreover, with top marginal income-tax rates falling from 70 percent in the early 1970s, to 50 percent in the early 1980s, and to under 40 percent today, corporate income tax (even with half of it shifted to consumers) may be the relatively more progressive tax.

Low income-tax rates also encourage wealthy CEOs to seek higher market incomes since they get to keep more of it (Piketty et al. 2014), and it gives the wealthy more money to influence policy decisions that can generate even more tax breaks for them (Bartels 2008). The result is rising inequality, less spending, and greater economic stagnation. A more progressive tax system, with greater revenues from the rich funding tax cuts for the poor and middle class, would stimulate spending and growth without increasing government debt.

We have tried radical monetary policy for several years, and many developed countries still suffer from high unemployment, stagnating incomes, and rising inequality. Fears of debt-deflation have not abated. Worse yet, in a few Anglo-Saxon nations we have had some rather undesirable political outcomes - likely the result of poor economic conditions (Pressman 2017). As this paper argues, we have reached the practical limits of radical monetary policy. It is time to try radical fiscal policy. ${ }^{5}$

5. The author thanks Tom Palley and two anonymous referees for their comments on an earlier version of this paper. The usual disclaimer applies. 


\section{REFERENCES}

Admati, A. and M. Hellwig (2013), The Bankers' New Clothes: What's Wrong with Banking and What to Do about It, Princeton, NJ: Princeton University Press.

Antolin, P., S. Schich, and J. Yermo (2011), 'The economic impact of protracted low interest rates on pension funds and insurance companies,' OECD Journal: Financial Market Trends, $1,1-20$.

Atesoglu, S. and J. Smithin (2006), 'Inflation targeting in a simple macroeconomic model,' Journal of Post Keynesian Economics, 28, 673-688.

Ball, L., J. Gagnon, P. Honohan, and S. Krogstrup (2016), 'What else can central banks do?' Geneva Reports on the World Economy 18, Geneva: International Center for Monetary and Banking Studies.

Bartels, L. (2008), Unequal Democracy: The Political Economy of the Gilded Age, Princeton, NJ: Princeton University Press.

Bartik, T. (2014), From Preschool to Prosperity: The Economic Payoff to Early Childhood Education, Kalamazoo, MI: W.E. Upjohn Institute.

Bech, M. and A. Malkhozov (2016), 'How have central banks implemented negative rate policies?' BIS Quarterly Review, March, 31-44.

Bernanke, B. (2007), 'The financial accelerator and the credit channel: the credit channel of monetary policy,' available at: http://www.federalreserve.gov/boarddocs/speeches/2007/ 20070615/default.htm.

Boivin, J., M. Kiley, and F. Mishkin (2010), 'How has the monetary transmission mechanism evolved over time?' in B. Friedman and M. Woodford (eds), Handbook of Monetary Economics, New York: Elsevier, pp. 369-422.

Bräuning, F. and B. Wu (2017), 'ECB monetary policy transmission during normal and negative interest rate periods,' available at: SSRN: https://ssrn.com/abstract=2940553 or http://dx.doi. org/10.2139/ssrn.2940553.

Burke, C., S. Hilton, R. Judson, K. Lewis, and D. Skeie (2010), 'Reducing the IOER rate: an analysis of options,' available at: https://www.federalreserve.gov/monetarypolicy/files/ FOMC20100805memo05.pdf.

Charles, S., T. Dallery, and J. Marie (2015), 'Why the Keynesian multiplier increases during hard times: a theoretical explanation based on rentiers' saving behaviour,' Metroeconomica, 66, 451-473.

Chick, V. (1983), Macroeconomics After Keynes, Cambridge, MA: MIT Press.

Coddington, A. (1976), 'Keynesian economics: the search for first principles,' Journal of Economic Literature, 14, 1258-1273.

Demiralp, S., J. Eisenschmidt, and T. Vlassopoulos (2017), 'Negative interest rates, excess liquidity and bank business models: banks' reaction to unconventional monetary policy in the Euro Area,' Koc University-TUSIAD Economic Research Forum Working Paper 1708.

Durden, T. (2016), 'There is now a staggering $\$ 11.7$ trillion in negative yield debt,' available at: http://www.zerohedge.com/news/2016-06-29/there-now-staggering-117-trillion-negativeyielding-debt.

ECB (European Central Bank) (2016), 'The Euro Area bank lending survey, first quarter of 2016,' Frankfurt am Main: European Central Bank.

Felix, A. and J. Hines (2009), 'Corporate taxes and union wages in the US,' NBER Working Paper No 15263.

Galbraith, J. (2016), Inequality: What Everyone Needs to Know, New York: Oxford University Press.

Garbade, K. and J. McAndrews (2012), 'If interest rates go negative ... or be careful what you wish for,' Liberty Street Economics, available at: http://libertystreeteconomics.newyorkfed. org/2012/08/if-interest-rates-go-negative-or-be-careful-what-you-wish-for.html.

Gesell, S. (1916 [1958]), The Natural Order, London: Owen.

Gnos, C. and L.-P. Rochon (2007), 'The New Consensus and Post-Keynesian interest rate policy,' Review of Political Economy, 19, 369-386. 
Hannoun, H. (2015), Ultra-Low or Negative Interest Rates: What they Mean for Financial Stability and Growth, Basel: Bank for International Settlements.

Heckman, J. and D. Masterov (2007), 'The productivity argument for investing in young children,' NBER Working Paper No 13016.

Heider, F., F. Saidi, and G. Schepens (2016), 'Life below zero: bank lending under negative policy rates,' European Central Bank and Stockholm School of Economics Working Paper.

Herndon, T., M. Ash, and R. Pollin (2014), 'Does high public debt consistently stifle economic growth? A critique of Reinhart and Rogoff,' Cambridge Journal of Economics, 38, 257-279.

Homer, S. and R. Sylla (2005), A History of Interest Rates, 4th edn, Hoboken, NJ: John Wiley.

IMF (International Monetary Fund) (2016), 'Global financial stability report: potential policies for successful normalization,' Washington, DC: International Monetary Fund.

Jobst, A. and H. Lin (2016), 'Negative interest rate policy (NIRP): implications for monetary transmission and bank profitability in the Euro Area,' IMF Working Paper 16/172.

Jobst, A. and H. Lin (2017), 'Are we there yet? Implications of negative interest rate for monetary transmission and bank profitability,' Zeitschrift für das Gesamte Kreditwesen, 69, 19-21.

Kahneman, D. and A. Tversky (1984), 'Choices, values, and frames,' American Psychologist, 39, 341-350.

Kelton, S. (2012), 'Liquidity preference,' in: J. King (ed.), The Elgar Companion to Post Keynesian Economics, 2nd edn, Cheltenham, UK and Northampton, MA: Edward Elgar Publishing, pp. 372-378.

Keynes, J.M. (1936), The General Theory of Employment, Interest and Money, London: Macmillan.

Krugman, P. (1998), 'It's baaack: Japan's slump and the return of the liquidity trap,'Brookings Papers on Economic Activity, 2, 137-187.

Lucas, R. (1981), Studies in Business Cycle Theory, Cambridge, MA: MIT Press.

Molyneux, P., A. Reghezza, J. Thornton, and R. Xie (2017), 'Did negative interest rates impact bank lending?' Bangor Business School Working Paper.

Okun, A. (1981), Prices and Quantities: A Macroeconomic Analysis, Washington, DC: Brookings Institution.

Palley, T. (2016), 'Why negative interest rate policy (NIRP) is ineffective and dangerous,' Real World Economic Review, 78, 5-15.

Patinkin, D. (1948), 'Price flexibility and full employment,'American Economic Review, 38, 543-564.

Pechman, J. (1985), Who Paid the Taxes, 1966-85? Washington, DC: Brookings Institution.

Pechman, J. and B. Okner (1974), Who Bears the Tax Burden? Washington, DC: Brookings Institution.

Phelps, E. (1972), Inflation Policy and Unemployment Theory, London: Macmillan.

Piketty, T. (2015), Capital in the Twenty-First Century, Cambridge, MA: Harvard University Press.

Piketty, T., E. Saez, and S. Stantcheva (2014), 'Optimal taxation of top incomes: a tale of three elasticities,' American Economic Journal: Economic Policy, 6, 230-271.

Pressman, S. (1994), 'The composition of government spending: does it make any difference?' Review of Political Economy, 6, 221-239.

Pressman, S. (1997), 'Consumption, income distribution and taxation: Keynes' fiscal policy,' Journal of Income Distribution, 7, 29-44.

Pressman, S. (2014), 'Beast of burden: the weight of inequality and the second Obama administration,' in C. Harrington (ed.), Obama's Washington: Political Leadership in a Partisan Era, London: University of London, pp. 89-112.

Pressman, S. (2017), 'The fall of the US middle class and the hair-raising ascent of Donald Trump,' Real-World Economics Review, 78, 112-124.

Reinhart, C. and K. Rogoff (2010), 'Growth in a time of debt,'American Economic Review, 100, $573-578$

Robinson, J. (1962), 'Review of Money, Trade and Economic Growth by H. Johnson,' Economic Journal, 72, 690-692. 
150 Review of Keynesian Economics, Vol. 7 No. 2

Rochon, L.-P. and M. Setterfield (2008), 'The political economy of interest-rate setting, inflation and income distribution,' International Journal of Political Economy, 37, 5-25.

Samuelson, P.A. (1948), 'The simple mathematics of income determination,' in L.A. Metzler et al., Income, Employment and Public Policy: Essays in Honor of Alvin H. Hansen, New York: W.W. Norton, pp. 133-155.

Scheiber, T., M. Silgoner, and C. Stern (2016), 'The development of bank profitability in Denmark, Sweden and Switzerland during a period of ultra-low and negative interest rates,' Focus on European Economic Integration, 3, 8-28.

Setterfield, M. (2015), 'Time variation in the size of the multiplier: a Kalecki-Harrod approach,' New School for Social Research Working Paper, 22/2015.

Siklos, P. (2017), Central Banks into the Breach: From Triumph to Crisis and the Road Ahead, New York: Oxford University Press.

Smithin, J. (2004), 'Interest rate operating procedures and income distribution,' in M. Lavoie and M. Seccareccia (eds), Central Banking in the Modern World, Cheltenham, UK and Northampton, MA: Edward Elgar Publishing, pp. 57-69.

Smithin, J. (2007), 'A real interest rate rule for monetary policy?' Journal of Post Keynesian Economics, 30, 101-118.

Stiglitz, J. (2010), Freefall, New York: W.W. Norton.

Vickrey, W. (1954), 'Stability through inflation,' in K. Kurihara (ed.), Post-Keynesian Economics, New Brunswick, NJ: Rutgers University Press, pp. 89-122.

Weintraub, S. (1961), Classical Keynesianism, Monetary Theory and the Price Level, Philadelphia: Chilton.

Wilcox, J. (1990), 'Nominal interest rate effects on real consumer expenditure,' Business Economics, 25, 31-37.

Witmer, J. and J. Yang (2015), 'Estimating Canada's effective lower bound,' Bank of Canada Staff Analytical Note 2015-2.

Wray, L.R. (2007), 'A Post Keynesian view of central bank independence, policy targets, and the rules versus discretion debate,' Journal of Post Keynesian Economics, 30, 119-141. 